\title{
Pericardial and diaphragmatic defect
}

INSERM

\section{Source}

INSERM. (1999). Orphanet: an online rare disease and orphan drug data base. Pericardial and diaphragmatic defect. ORPHA:2847

Pericardial and diaphragmatic defect is a rare combination of absent pericardium with congenital diaphragmatic defect. 